\title{
Characteristics of Members of Board Committees at Borsa Istanbul
}

\author{
Emrah Arioglu ${ }^{1} \&$ Koray Tuan ${ }^{1}$ \\ ${ }^{1}$ School of Business Administration, Cukurova University, Adana, Turkey \\ Correspondence: Emrah Arioglu, Cukurova University IIBF Isletme Bolumu, Balcali, Adana, Turkey. Tel: \\ 90-530-490-0592. E-mail: earioglu@cu.edu.tr
}

Received: October 14, 2014

Accepted: October 24, 2014

Online Published: November 25, 2014

doi:10.5539/ijef.v6n12p83

URL: http://dx.doi.org/10.5539/ijef.v6n12p83

\begin{abstract}
In this study, we investigate the characteristics of members of audit, risk and governance committees of boards in public firms quoted at Borsa Istanbul, with an emphasis on their educational backgrounds, professional expertise, independence, busyness, share ownership and managerial positions. Our findings show that a lower percentage of members of these committees, compared to non-members, serve as the chairmen of boards. In addition, a higher percentage of them are independent, have advanced educational degrees, and are professional experts such as accounting experts, lawyers, professors. The findings also show that members of these committees own fewer shares and serve on fewer outside boards. Interestingly, the findings show that a very low percentage of directors that do not serve on these committees are independent directors, leading to the question of what the underlying motivation for the inclusion of independent directors on boards of directors is.
\end{abstract}

Keywords: audit committee, board committees, borsa Istanbul, governance committee, risk committee

\section{Introduction}

The committees in the boards of directors of public firms have received intensive attention in corporate governance literature in developed markets. In the recent years, the committees have also been the subject of research on Turkish capital markets, with a main focus on audit committees. Among these papers are those by Ozsoy (2012), Nuhoglu and Armagan (2013), Catikkas and Alpaslan (2013), Karasu (2013), and Kandemir and Akbulut (2013). However, it is difficult to state that any of these studies focus on all of the common committees of the boards - audit committee, (corporate) governance committee and (early determination of) risk committee with an emphasis on the characteristics and qualifications of directors serving on these committees. In this study, we attempt to fill this gap in the literature. As discussed in the following paragraphs and sections, the qualifications, such as professional expertise or independence, of directors on these committees would be expected to have an impact the effectiveness of oversight provided by them (Dionne \& Triki, 2005; Dionne et al., 2013). Therefore, we focus on the characteristics and qualifications of directors serving on the audit, governance and risk committees of the boards of directors of firms quoted at the National and Secondary markets of Borsa Istanbul in 2012 and 2013.

Before summarizing our findings, we believe that it is important to discuss why the existence of various board committees in firms is vital. The board of directors exists as one of the strongest corporate governance mechanisms to ensure that the interests of shareholders of the company are protected and agency costs are minimized. However, it is possible that some directors in the boards could avoid their responsibilities. A potential mechanism to prevent this kind of problem from occurring is setting various board committees. Members of these committees, in addition to their other duties, could be helpful in establishing oversight over the members of board of directors. The committees also serve as mechanisms, to which part of managerial power is devolved to (Hopt \& Leyens, 2004), as a potential mechanism against powerful CEOs or chairmen.

In corporate governance literature regarding developed markets, the three committees that have received the most attention are audit committee, compensation committee and nominating committee (Yermack, 1997; Klein, 2002; Anderson \& Bizjak, 2003; Conyon \& He, 2004; DeFond et al., 2005; Gordon, 2005; Agrawal \& Chadha, 2005). In US markets, SEC has been setting independence requirements for the members of these directors, in the last decade, especially following the Sarbanes-Oxley Act. In addition, the SEC requires at least one financial expert to sit on the audit committee of public firms, even though some researchers argue that these requirements might be unnecessary (Le Mire \& Gilligan, 2013; Karmel, 2014). 
The main reason underlying the requirements for independence of the members of these committees is the widely held belief in markets that independent directors are more effective monitors, compared to insiders or gray directors, since they have no ties to the company, other than the directorship position they. As a result, it is expected that the decisions of these directors in various board committees, would be aligned with the interest of shareholders, rather than the interests of the managers of companies hold (Jensen, 1993; Jensen \& Murphy, 2004; Perry \& Shivdasani, 2005; Knyazeva et al., 2013). Indeed, each of the various committees of boards would function in a unique way to ensure the alignments of interests and the reduction of agency costs. However, we leave the discussions regarding the importance and effectiveness of each committee to the relevant following sections of the paper.

In section 3, we investigate the characteristics and qualification of directors that serve on audit committees of companies. Our findings reveal that a significantly lower percentage of members of audit committees, compared to non-audit committee members, are chairmen of boards. In addition, almost all of them are independent directors. On the other hand, interestingly, a very low percentage of directors that are not audit committee members are independent, raising the question of why public firms appoint independent directors to boards. Is it just to meet the independence requirements of the Principles of Corporate Governance (PCG), which regulates corporate governance related issues for Turkish public firms, or do they really believe in the effectiveness of independent directors? Our findings also reveal that a significantly lower percentage of audit committee members are foreigners, compared to other directors, whereas a significantly higher percentage of them have PhDs, and are accounting experts, lawyers or professors. In addition, our findings show that a significantly higher percentage of audit committee members are also members of governance committees and risk committees. Lastly, the members of audit committees serve on significantly lower number of outside boards and they own significantly less shares in firms.

In section 4 , we investigate the characteristics of members of corporate governance committees. Our findings show that a very small portion of these directors are chairmen in boards, whereas a significantly higher percentage of governance committee members are independent directors, compared to non-governance committee member directors. In addition, a significantly higher percentage of governance committee members are professional experts that are accounting experts, lawyers or professors, and a higher percentage of them have $\mathrm{PhDs}$ degrees. Also, a significantly higher percentage of them serve on audit and risk committees, as well. Lastly, their average directorship numbers and share ownerships in firms are significantly lower, compared to non-governance committee members.

In section 5, we investigate some of the corporate governance issues related to the members of risk committees. Except the case of lawyers and average directorship held by the members of these committees, we observe parallel patterns for the members of risk committees, regarding their educational backgrounds, professional expertise, other committee memberships, share ownership and busyness. Lastly, in section 6, we investigate the existence of these committees in public firms and what percentage of them include only independent directors. Our findings show that a very high percentage of firms had audit and governance committees existing in their boards. Also, a very high percentage of the audit committees had only independent directors serving on them, whereas a low percentage of governance committees included only independent directors. Lastly, our findings show that a low percentage of firms had risk committees in their boards at the end of 2012, and a high percentage of them had this committee by the end of the following year. Yet, a very low percentage of these committees included only independent directors in them.

One point is noteworthy before proceeding. The reason for the choice of years analyzed in this study is the availability of detailed information regarding director backgrounds for the majority of firms quoted at Borsa Istanbul, following the PCG becoming effective in 2012, promoting transparency and the disclosure of information by firms to the public.

\section{Data and Method}

We use hand collected data covering public firms quoted at the National and Secondary markets of Borsa Istanbul at the end of the years 2012 and 2013. The data is gathered from the annual reports of firms and the official web pages of companies. Banks are excluded from the sample since they are subject to some unique corporate governance regulations, compared to other firms. As a result, our sample covers 2079 directors for 2012 and 2066 directors for 2013. In addition, data for some of the variables, such as education or age, employed in this study is not available for all the directors on the board of directors.

Throughout the study, the highest level of degree earned by a director is defined by the education level, whereas abroad education variable states whether the director has earned a degree from an institution, located outside of 
Turkey. In addition, a director is categorized as a finance expert if she has been or currently is the CEO or on the board of a financial institution. A director is categorized as an accounting expert is she certifies as a CPA or equivalent. Professor defines whether the director officially has or had a professor title, either on a tenure track or clinical. Lawyer defines that the director has a law degree. Share ownership by directors states the percentage of shares owned by a director alone in the focal company. An individual is defined as a busy director, if she is an independent director on the focal firm and is on the board of at least three different firms that are not non-profits, following Fich and Shivdasani (2006). Committee membership variables state whether the director serves in either audit, governance or risk committee. A director is defined as an independent director if she meets the independence requirements defined in PCG. Lastly, the membership number of the director states the total number of firms, that are not non-profit, whose boards the director sits on.

Table 1. Descriptive statistics

\begin{tabular}{lrr}
\hline \multicolumn{3}{c}{ Director Characteristics } \\
\hline Number of Directors & 2012 & 2013 \\
Audit Committee Member & 2079 & 2066 \\
Governance Committee Member & 551 & 559 \\
Risk Committee Member & 628 & 664 \\
Independent Member & 236 & 487 \\
PhD Degree & 607 & 613 \\
Masters Degree & 181 & 186 \\
College Degree & 567 & 543 \\
High School or Lower Degree & 1006 & 1016 \\
Abroad Education & 91 & 86 \\
Busy Director & 778 & 753 \\
Finance Expert & 171 & 195 \\
Accounting Expert & 745 & 769 \\
Lawyer & 210 & 213 \\
Professor & 126 & 111 \\
\hline
\end{tabular}

The descriptive statistics regarding the sample are presented in Table 1. The Table shows that at the end of 2012 , 551 directors served on audit committees, 628 served on governance committees, and 236 served on risk committees. The values for these figures, at the end of 2013, are 559, 664, and 487, consecutively. Out of around 2000 directors at the end of both years, around 600 are independent directors. Almost half of the directors in the sample have college degrees as the highest level of educational degrees earned, at the end of both years. A substantial amount of the directors have degrees earned from institutions that are not located in Turkey. At the end of 2012, 171 and at the end of 2013, 195 of the directors in the sample are busy directors. In addition, a substantial amount of these directors have financial expertise, whereas directors who are accounting experts, professors or lawyers do not make up a high percentage of the sample.

\section{Audit Committees}

The first committee we investigate is the audit committee, among whose main responsibilities are selecting the independent auditor for the company, reviewing the financial statements of the company, overseeing the independence of the auditor, providing oversight to the internal control mechanisms of the company, and preventing fraudulent behavior and actions (Arioglu, 2013). It is important that the members of a committee with such vital responsibilities are effective monitors. The effectiveness of directors and the proper functioning of this committee could be ensured by selecting directors, who have the necessary knowledge, technical skills and are independent from top management, as committee members. For instance, selecting foreign directors to this committee could potentially, but necessarily, impair the effectiveness of the functioning of the committee in the case that the foreign director does not have technical knowledge regarding the accounting applications and regulations in Turkey (Masulis et al., 2012). This is also why in some developed markets, there are regulations requiring the members of this committee to be independent directors with financial expertise, as well as in Turkish capital markets.

The effectiveness of monitoring by the audit committee would be expected to be a very important factor especially in the instances of corporate fraud, since fraud would definitely affect firm value negatively. DeChow 
et al. (1996), Klein (2002), Uzun et al. (2004), and Soliman and Ragab (2014) provide evidence supporting this argument, whereas Beasley (1996), Anderson et al. (2003), and Agrawal and Chadha (2005) provide counter evidence.

In addition, the existence of a finance of accounting expert would be expected to improve the quality of the work and decisions made by the audit committee. Investigating this topic, Defond et al. (2005) show that audit committees could help create value when they include financial experts, who are valuable sources in overseeing financial statements. As would be expected, the types of financial experts that receive positive reactions from the market are the accounting financial experts, rather than the non-accounting financial experts, since accounting experts are expected to have superior accounting related knowledge. Agrawal and Chadha (2005), Badolato et al. (2014), Soliman and Ragab (2014), and Albring et al. (2014) provide evidence supporting the importance of the accounting expertise of these directors.

On the other hand, one could potentially argue that even though the independence of members of the committee would provide the benefits of independence of directors, it could also potentially be costly for the firm since these directors could lack firm specific important information related to the firm's internal control mechanism (Anderson et al., 2003). Choi et al. (2014) provide evidence suggesting that the characteristics of the members of audit committees could alter the soundness of corporate governance structure of firms.

In light of these arguments, our results regarding the characteristics of audit committee members are presented in Table 2. The Table shows that out of the 559 directors, who were on audit committees of firms at the end of 2013 , none of them were the CEOs of the firms. On the other hand, only $0.90 \%$ of them were the chairmen of firms, which is significantly lower, compared to directors that did not serve on audit committees. In terms of the argument that the committees of the boards exist not only to discuss, advice and govern certain issues, but also to provide monitoring over the whole board and naturally its chairman, this figure suggests that public firms, on average, were able to provide the existence of an effective monitoring mechanism.

In addition, a significantly higher percentage of these directors, compared to other directors, were independent directors, $97.67 \%$. What is an interesting figure is the very low percentage of directors that are not audit committee members and are independent. Only $3.63 \%$ of non-audit committee member directors were independent directors. This figure could be considered as suggesting that the main reason companies appoint independent directors to boards is so that they can serve on committees of the boards, such as audit committees, which are subject to independence requirements.

What Table 2 also shows is that a significantly lower percentage of the members of audit committees were foreign directors, $4.65 \%$. This could be an outcome of the potential concerns that foreign directors might not have the necessary knowledge about the accounting and financial reporting applications of Turkish public firms. In terms of education levels of these directors, Table 2 shows that a significantly higher percentage of audit committee members have advanced degrees such as PhDs, $18.34 \%$. Based on this figure, one could argue that boards value potential skills gained through educational degrees that provide the individuals with specific technical skills, and thus appoint them to audit committees, where their technical skills would be of great value.

Table 2 also shows that a significantly higher percentage of members of audit committees are professional experts, compared to non-audit committee members, such as accounting experts, lawyers or professors. $18.45 \%$ of the audit committee members are accounting experts, whereas $10.30 \%$ are lawyers and $15.38 \%$ are professors. The same cannot be stated for financial expertise of these directors. This could be an outcome of the definitions regarding professional expertise of directors. The definition of financial expertise does not require any technical requirements, whereas the other three do. Therefore, one could argue that firms potentially value the technical skills of these professionals and appoint them to audit committees, in order to benefit from their expertise and unique skills and knowledge.

On the other hand, Table 2 also shows that, compared to non-audit committee member directors, a significantly higher percentage of audit committee members are also members of governance committees and risk committees, $60.11 \%$ and $48.12 \%$, consecutively. Firms appear to appoint directors to more than one committee at the same time. It could potentially be an outcome of the belief that the pool of talented director candidates are limited and thus firms prefer to appoint directors that would have the technical skills required for effective monitoring in all the committees of the boards.

Table 2 also presents the percentage of audit committee members that are busy directors. A significantly higher percentage of them are busy directors, $32.95 \%$, whereas only $1.49 \%$ of non-audit committee member directors are busy. Based on this observation, one could, at first, suggest that firms prefer to appoint directors that serve on other firms' committees, to their audit committees, potentially as a result of the belief that these directors could 
gain valuable skills through their directorships in other firms. However, this is not the case. The figures regarding the percentage of directors that are busy is an outcome of the requirement of the definition of director busyness. Since a very small amount of non-audit committee member directors are independent, they do not get to qualify as busy directors, in the first place. As presented in Table 2, audit committee members, on average, serve on 2.49 boards, whereas the other directors serve on 3.83 boards, which is significantly higher. This figure supports the argument by Jiraporn et al. (2009) that directors serving on many boards could have time constraints and might not have the time to attend the meetings of committees. Thus, they are not appointed to committees.

Table 2. Audit committee members

\begin{tabular}{|c|c|c|c|c|}
\hline & \multicolumn{2}{|c|}{2012} & \multicolumn{2}{|c|}{2013} \\
\hline & $\begin{array}{l}\text { Audit Committee } \\
\text { Member }\end{array}$ & $\begin{array}{l}\text { Not Audit } \\
\text { Committee Member }\end{array}$ & $\begin{array}{l}\text { Audit Committee } \\
\text { Member }\end{array}$ & $\begin{array}{l}\text { Not Audit } \\
\text { Committee Member }\end{array}$ \\
\hline Number of Directors & 551 & 1426 & 559 & 1461 \\
\hline CEO in Firm & $* * * 0.00 \%$ & $10.16 \%$ & $* * * 0.00 \%$ & $9.86 \%$ \\
\hline Female & $* * * 7.44 \%$ & $12.97 \%$ & $* * * 7.51 \%$ & $12.46 \%$ \\
\hline Chairman & $* * * 0.91 \%$ & $19.03 \%$ & $* * * 0.90 \%$ & $18.46 \%$ \\
\hline Independent & $* * * 96.91 \%$ & $3.50 \%$ & $* * * 97.67 \%$ & $3.63 \%$ \\
\hline Foreigner & $* * * 5.08 \%$ & $13.18 \%$ & $* * * 4.65 \%$ & $14.17 \%$ \\
\hline PhD Degree & $* * * 18.58 \%$ & $6.45 \%$ & $* * * 18.34 \%$ & $7.12 \%$ \\
\hline Masters Degree & $* * 26.66 \%$ & $33.04 \%$ & $* * 24.26 \%$ & $32.23 \%$ \\
\hline Bachelor Degree & $* * 52.92 \%$ & $62.23 \%$ & $55.02 \%$ & $55.15 \%$ \\
\hline Abroad Education & $* * * 37.25 \%$ & $44.86 \%$ & $* * * 34.26 \%$ & $44.52 \%$ \\
\hline Financial Expert & $43.08 \%$ & $39.37 \%$ & $43.60 \%$ & $40.80 \%$ \\
\hline Accounting Expert & $* * * 20.04 \%$ & $7.91 \%$ & $* * * 18.45 \%$ & $8.52 \%$ \\
\hline Lawyer & $* * * 9.66 \%$ & $5.37 \%$ & $* * * 10.30 \%$ & $4.03 \%$ \\
\hline Professor & $* * * 14.99 \%$ & $2.72 \%$ & $* * * 15.38 \%$ & $2.64 \%$ \\
\hline Governance Committee Member & $* * * 56.47 \%$ & $22.36 \%$ & $* * * 60.11 \%$ & $22.45 \%$ \\
\hline Risk Committee Member & $* * * 22.95 \%$ & $7.73 \%$ & $* * * 48.12 \%$ & $14.92 \%$ \\
\hline Age & $* * * 56.42$ & 53.55 & $* * * 56.71$ & 53.98 \\
\hline Share Ownership & $* * * 0.16 \%$ & $2.78 \%$ & $* * * 0.03 \%$ & $2.95 \%$ \\
\hline Busy Director & $* * * 30.46 \%$ & $1.02 \%$ & $* * * 32.95 \%$ & $1.49 \%$ \\
\hline Average Membership Number & $* * * 2.38$ & 3.75 & $* * * 2.49$ & 3.83 \\
\hline
\end{tabular}

Note. $* * *, * *$, and $*$ present significance at $1 \%, 5 \%$, and $10 \%$ levels.

Lastly, what we observe in the Table 2 is the share ownership by audit committee members. Compared to other directors, who own on average $2.95 \%$ of the shares of firms, these directors, on average, own only $0.03 \%$ of the shares of companies. This could be an outcome of the PCG requirement that independent directors cannot own more than $1 \%$ of the shares of firms, and the directors on audit committees are independent directors. Still, it could be argued that such a requirement might cost other shareholders of companies, since potential benefits of shareholding incentives of directors (Stulz, 1988; Morck et al., 1988; McConnell \& Servaes, 1990; Hermalin \& Weisbach, 1991) in aligning their interests with those of other shareholders could be forgone. Similar figures are observed, for the end of the year 2012.

In future studies, it would be especially interesting to investigate the reaction given by the market, to the appointments of accounting or finance experts, to the audit committees, as well as examining the changes in firm performance following these appointments. Indeed, similar studies could be conducted following the departures of such experts from audit committees.

\section{Corporate Governance Committees}

Another important committee commonly established in most public companies quoted at Borsa Istanbul is the corporate governance committee. In developed markets such as US, this committee is usually named as "nominating and corporate governance" committee (Gillan et al., 2003; Arioglu, 2013). Even the PCG of Turkey states that in the case that a separate nomination committee is not established, the duties of the committee is exercised by the governance committee of the board. Thus, it is reasonable to assume that the discussions regarding nomination committees would apply to governance committees. 
As it is the case with audit committees, the most important issue regarding governance committees is the independence of its members (Hopt \& Leyens, 2004). In public companies, powerful CEOs or chairmen could potentially dominate the director nomination process, where they could tend to nominate directors that would not challenge her decisions (Borokhovich et al., 1996). The existence of independent directors on the governance committee, therefore, is important to limit the power that the CEO or the chairman could possess in the nomination process. Based on the effectiveness arguments regarding independent directors, one could suggest that a governance committee dominated by independent directors could serve to protect shareholders' interests more effectively.

Supporting this argument, Shivdasani and Yermack (1999) provide evidence suggesting that when the CEO is involved in nomination process, the directors that are chosen are the ones, who are less likely to monitor effectively. The researchers show that in such a nomination process, a lower fraction of independent directors are selected and the likelihood of an independent board is lower. In addition, negative announcement abnormal returns are observed following director appointments. Gillan et al. (2003) show that among S\&P 1500 companies in US, $57 \%$ of the firms have nominating committees, with $71 \%$ of the members being independent, and $23 \%$ of them have separate corporate governance committees. In addition, once again, the expertise of the members of these boards would be expected to be an important factor, as well as their busyness and board appointments in other companies, due to time constraints to attend all meetings of committees (Jiraporn et al., 2009).

Our findings regarding the members of governance committees of boards of public firms quoted at Borsa Istanbul are presented in Table 3. The Table shows that in our sample, 664 directors are members of governance committees of boards, at the end of 2013, whereas 628 were, at the end of 2012. The Table also shows that, in accordance with PCG requirements, none of the governance committee members are CEOs in firms. In addition, a significantly lower percentage of directors are chairmen in firms, $2.59 \%$, compared non-committee member directors. Thus our discussion regarding the findings of the previous section would apply here, as well.

In addition, what is observed in Table 3 is that slightly more than half of the directors on governance committees are independent directors, $53.92 \%$, which is significantly higher than the percentage of non-governance committee members that are independent. The figures suggest that firms prefer to appoint a higher percentage of independent directors to governance committees. This could be an outcome of the belief that independent directors could be free of pressures from the CEO or the chairman of the board and could provide more effective monitoring, compared non-independent directors.

Table 3. Governance committee members

\begin{tabular}{|c|c|c|c|c|}
\hline & \multicolumn{2}{|c|}{2012} & \multicolumn{2}{|c|}{2013} \\
\hline & Governance & Not $\quad$ Gov. & Governance & Not Gov. \\
\hline & Committee Member & Committee Member & Committee Member & Committee Member \\
\hline Number of Directors & 628 & 1343 & 664 & 1356 \\
\hline CEO in Firm & $* * * 0.00 \%$ & $10.57 \%$ & $* * * 0.00 \%$ & $10.47 \%$ \\
\hline Female & $10.51 \%$ & $11.84 \%$ & $10.39 \%$ & $11.43 \%$ \\
\hline Chairman & $* * * 3.23 \%$ & $18.96 \%$ & $* * * 2.59 \%$ & $19.15 \%$ \\
\hline Independent & $* * * 53.18 \%$ & $18.47 \%$ & $* * * 53.92 \%$ & $17.77 \%$ \\
\hline Foreigner & $* 9.08 \%$ & $11.54 \%$ & $* 9.79 \%$ & $12.39 \%$ \\
\hline PhD Degree & $* * 13.77 \%$ & $8.06 \%$ & $* * * 14.64 \%$ & $8.13 \%$ \\
\hline Masters Degree & $* 28.44 \%$ & $32.33 \%$ & $* 27.10 \%$ & $31.39 \%$ \\
\hline Bachelor Degree & $54.91 \%$ & $54.53 \%$ & $55.55 \%$ & $54.90 \%$ \\
\hline Abroad Education & $* * * 36.74 \%$ & $45.41 \%$ & $* * * 35.47 \%$ & $44.67 \%$ \\
\hline Financial Expert & $40.83 \%$ & $40.25 \%$ & $43.99 \%$ & $40.41 \%$ \\
\hline Accounting Expert & $* * * 17.10 \%$ & $8.66 \%$ & $* * * 17.52 \%$ & $8.25 \%$ \\
\hline Lawyer & $* * * 8.94 \%$ & $5.47 \%$ & $* * * 7.81 \%$ & $4.80 \%$ \\
\hline Professor & $* * * 9.45 \%$ & $4.61 \%$ & $* * * 10.06 \%$ & $4.32 \%$ \\
\hline Audit Committee Member & $* * * 49.36 \%$ & $17.79 \%$ & $* * * 50.60 \%$ & $16.45 \%$ \\
\hline Risk Committee Member & $* * * 20.54 \%$ & $7.96 \%$ & $* * * 43.67 \%$ & $14.53 \%$ \\
\hline Age & 54.41 & 54.34 & 54.83 & 54.73 \\
\hline Share Ownership & $* * * 0.61 \%$ & $2.73 \%$ & $* * * 0.54 \%$ & $2.93 \%$ \\
\hline Busy Director & $* * * 16.43 \%$ & $5.91 \%$ & $* * * 17.62 \%$ & $6.68 \%$ \\
\hline Average Membership Number & $* * * 3.06$ & 3.51 & $* * 3.18$ & 3.61 \\
\hline
\end{tabular}

Note. $* * * * *$, and $*$ present significance at $1 \%, 5 \%$, and $10 \%$ levels. 
On the other hand, Table 3 also shows that in terms of the percentage of directors that are foreigners, governance committee members do not differ from non-committee members, statistically. The opposite was observed for audit committees. However, the fact that firms do not differentiate in director appointments to the committees, in terms of national backgrounds could be considered as additional support to the discussion that foreign directors are not appointed to audit committees as a result of potential lack of knowledge regarding unique accounting applications in Turkey.

In terms of educational background and professional expertise, we observe parallel figures to those observed for audit committee members. Thus, the discussion we had about the importance of technical skills required in the committees of boards would apply to the case of governance committee members. However, one could argue that governance committees' duties would not require specific technical skills, and a higher percentage of governance committee members turn out to professional experts for no special reason. $14.64 \%$ of these directors have PhDs, whereas $17.52 \%$ of them are accounting experts, $7.81 \%$ are lawyers, and $10.06 \%$ are professors.

In addition, as observed for audit committee members, a significantly higher percentage of governance committee members sit on audit and risk committees, $50.60 \%$ and $43.67 \%$, consecutively, compared to non-governance committee member directors. As we discussed earlier, this could be an outcome of the belief that the pool of talented director candidates are limited and thus firms prefer to appoint these directors to other committees of the boards, as well.

Once again, as in the case of audit committee members, even though a significantly higher percentage of governance committee members are busy directors, $17.62 \%$, compared to other directors, the average directorship numbers of these directors are significantly lower, 3.18 directorships on average, compared to directors that do not serve on governance committees. As discussed before, the effects on independence requirements in the definition of busyness and the time constraints that directors serving on various boards and board committees would have, should be kept in mind. Lastly, what we observe in Table 3 is that the average share ownership by members of governance committees are significantly lower, $0.54 \%$, compared to other directors. Similar findings are obtained for the end of 2012.

\section{Early Determination of Risk Committees}

The previous discussions we had regarding the effectiveness of other committees of the board could mostly apply to (early determination of) risk committees. However, the audit committees' main focus could be stated as auditing and financial reporting related issues, and the governance committees' focus could be stated as the application of the principles of corporate governance by companies, whereas risk committees' main focus could be considered as the determination of risks that could endanger the existence, growth and continuation of the company and the precautions to be taken against these risks. Thus, some issues and discussions related to risk committees, more than to other committees, would arise.

The risk committee would be expected to be responsible for the determination of the risk tolerance level of the firm, which is indeed a very important topic for firms especially following the recent financial crises around the globe. One could easily argue that one of the main reasons underlying the crises was the failure of boards to identify potential risks (Walker, 2009). We could expect that directors with unique professional expertise such as financial expertise, or with advanced degrees such as PhDs to be useful additions to the risk committees of the firms, in assessing these potential risks that the firm could face and potential remedies to cope with these risks (Tao \& Hutchinson, 2013).

The members of risk committees would be expected to have skills to detect fundamental risks that are related to the leverage of the firm, or liquidity risks, or risks such as interest rate and currency risks (Walker, 2009). Directors with unique professional expertise such as business professors, who are on boards of public firms, would be expected to have technical understanding of these topics. In addition to the expertise arguments, the arguments regarding the effectiveness of monitoring by board members, who are independent directors, could also apply to the risk committee members, as well (Tao \& Hutchinson, 2013). Thus, one could recommend that these committees are comprised of independent directors. Still, such requirements would potentially undermine the importance of the industry specific knowledge of the executives of the firm, who could potentially be members of the risk committee.

Before we present our findings, it is also useful to note that, one cannot expect every firm to benefit from the existence of a risk committee at the same level. Yatim (2010) provide evidence in support of this argument. In addition, risk committees could be expected to be even more important for firms in such industries that involve higher levels of uncertainty, or in other words, risk (Tao \& Hutchinson, 2013). Similarly, Subramaniam et al. (2009) show that the need for risk management committees varies with board size. Nkoko and Tesfaye (2014) 
also show that there is a relationship between the existence of risk committees and firm size and industry.

Our findings are presented in Table 4. The Table shows that, among directors in our sample, 236 are on risk committees of boards, at the end of 2012, whereas 487 serve on risk committees at the end of 2013. In terms of their characteristics and qualifications, as well as other corporate governance related issues, we observe similar figures compared to the members of audit and governance committee members. None of the members of these committees are CEOs of their companies, at the end of 2013, whereas a significantly lower percentage of them are chairmen in firms, $3.13 \%$, compared to non-risk committee member directors. In addition, a significantly higher percentage of them are independent directors, $58.11 \%$, have $\mathrm{PhD}$ degrees, $15.29 \%$, are accounting experts, $15.87 \%$, and are professors, $10.04 \%$. We have already discussed the potential interpretations of similar results in the previous two sections, thus we believe that the same arguments would apply to the figures observed in Table 4.

Table 4. Risk committee members

\begin{tabular}{|c|c|c|c|c|}
\hline & \multicolumn{2}{|c|}{2012} & \multicolumn{2}{|c|}{2013} \\
\hline & $\begin{array}{l}\text { Risk Committee } \\
\text { Member }\end{array}$ & $\begin{array}{l}\text { Not Risk Committee } \\
\text { Member }\end{array}$ & $\begin{array}{l}\text { Risk Committee } \\
\text { Member }\end{array}$ & $\begin{array}{l}\text { Not Risk Committee } \\
\text { Member }\end{array}$ \\
\hline Number of Directors & 236 & 1735 & 487 & 1533 \\
\hline CEO in Firm & $* * * 0.00 \%$ & $8.36 \%$ & $* * * 0.00 \%$ & $9.39 \%$ \\
\hline Female & $14.41 \%$ & $11.01 \%$ & $9.45 \%$ & $11.61 \%$ \\
\hline Chairman & $* * * 3.02 \%$ & $15.43 \%$ & $* * * 3.13 \%$ & $17.05 \%$ \\
\hline Independent & $* * * 56.78 \%$ & $25.82 \%$ & $* * * 58.11 \%$ & $20.61 \%$ \\
\hline Foreigner & $* 14.41 \%$ & $10.26 \%$ & $11.50 \%$ & $11.55 \%$ \\
\hline PhD Degree & $* * * 15.32 \%$ & $9.09 \%$ & $* * * 15.29 \%$ & $10.09 \%$ \\
\hline Masters Degree & $28.82 \%$ & $31.42 \%$ & $* 26.38 \%$ & $31.18 \%$ \\
\hline Bachelor Degree & $53.60 \%$ & $54.80 \%$ & $55.65 \%$ & $54.93 \%$ \\
\hline Abroad Education & $42.79 \%$ & $42.63 \%$ & $41.46 \%$ & $41.69 \%$ \\
\hline Financial Expert & $44.74 \%$ & $39.82 \%$ & $* 45.22 \%$ & $40.38 \%$ \\
\hline Accounting Expert & $* * 15.79 \%$ & $10.70 \%$ & $* * * 15.87 \%$ & $9.79 \%$ \\
\hline Lawyer & $8.19 \%$ & $6.36 \%$ & $7.25 \%$ & $5.31 \%$ \\
\hline Professor & $* * 9.91 \%$ & $5.63 \%$ & $* * * 10.04 \%$ & $4.97 \%$ \\
\hline Audit Committee Member & $* * * 53.39 \%$ & $24.38 \%$ & $* * * 55.24 \%$ & $18.92 \%$ \\
\hline Governance Committee Member & $* * * 54.66 \%$ & $28.76 \%$ & $* * * 59.55 \%$ & $24.40 \%$ \\
\hline Age & 55.01 & 54.27 & 54.61 & 54.82 \\
\hline Share Ownership & $* * * 0.69 \%$ & $2.24 \%$ & $* * * 0.59 \%$ & $2.64 \%$ \\
\hline Busy Director & $* * * 19.72 \%$ & $7.84 \%$ & $* * * 21.33 \%$ & $6.70 \%$ \\
\hline Average Membership Number & 3.34 & 3.37 & 3.41 & 3.47 \\
\hline
\end{tabular}

Note. $* * * * *$, and $*$ present significance at $1 \%, 5 \%$, and $10 \%$ levels.

In addition, what we observe in Table 4 is that, once again as in the case of members of other two committees, a higher percentage of risk committee members serve on the other two committees, compared to non-risk committee member directors. Also, the average share ownership by the members of risk committee members is significantly lower, $0.59 \%$, compared to other directors. Once again, we believe that our previous discussions in the previous two sections would apply to these figures, as well. However, in the case of risk committee membership, what we observe is that the average directorship positions held by the members of risk committees do not differ statistically, from the membership number of non-risk committee member directors. For the end of the year 2012, we obtain almost parallel figures.

\section{Committee Members vs. Non-Committee Members}

So far, we have investigated various corporate governance related issues concerning committee memberships of directors in the boards. In this last section, we present the figures regarding the number of public firms with any of these committees existing, and the independence of these committees. Our findings are presented in Table 5.

Table 5 shows that, at the end of 2012, out of the 290 firms in our sample, 273 had audit committees, 257 which comprised of only independent directors, and 2 had no existing audit committees. At the end of 2013, out of 287 firms in our sample, 278 had audit committees and 1 had no audit committee. 266 of the audit committees 
comprised solely of independent directors. Even though the PCG requires all the members of these committees to be independent directors, the fact that some did not comply with this requirement could be an outcome of companies that just went public by the end of both years and thus could not comply with the requirements. The average member number on these boards was 2.04 and 2.05, at the end of 2012 and 2013, consecutively.

On the other hand, Table 5 shows that at the end of 2012, 267 of the firms in the sample had governance committees, whereas 276 had governance committee, at the end of 2013. In both years, 46 of these committees had only independent directors serving on them. The average number of directors serving on these committees was 2.47 at the end of 2012, and 2.57 at the end of 2013 .

Table 5. Committee existence and independence

\begin{tabular}{lll}
\hline & $\mathbf{2 0 1 2}$ & $\mathbf{2 0 1 3}$ \\
\hline Number or Firms & 290 & 287 \\
Audit Committee & 273 & 278 \\
No Audit Committee & 2 & 1 \\
Independent Audit Committee & 257 & 266 \\
Committee Size & 2.04 & 2.05 \\
Governance Committee & 267 & 276 \\
No Governance Committee & 7 & 3 \\
Independent Governance Committee & 46 & 46 \\
Committee Size & 2.47 & 2.57 \\
Risk Committee & 103 & 217 \\
No Risk Committee & 170 & 61 \\
Independent Risk Committee & 15 & 41 \\
Committee Size & 2.81 & 2.55 \\
\hline
\end{tabular}

Lastly, Table 5 shows that at the end of 2012, 103 firms had risk committees and 170 had no risk committees. 15 of these committees had solely independent directors serving on them. However, at the end of 2013, we observe that 217 of the firms had risk committees, 41 of which had only independent directors serving on them. 61 of the firms, on the other hand, had no risk committees. The average numbers of directors serving on these boards were 2.81 at the end of 2012, and 2.55 at the end of 2013 .

\section{Discussion}

Substantial attention has been paid to the audit committees of public firms in Turkey. However, the same cannot be stated for other common committees of boards of public firms: corporate governance committees and early determination of risk committees. In this study, to fill this gap in the literature, we investigate the characteristics and qualifications of members of these three committees in public firms quoted at the National and Secondary markets of Borsa Istanbul, with an emphasis on members' educational backgrounds, professional expertise, independence, busyness, share ownership and managerial positions.

Our findings show that significantly lower percentage of members of these committees, compared to non-members, serves as the chairmen of boards. Based on the arguments that the members of committees of the boards are expected to provide monitoring over the whole board and the chairman, our findings suggest that members of boards could have the opportunity to monitor effectively, free of pressure from the chairman of the board, at least in theory, even though not necessarily. In future studies, researchers could potentially investigate the involvement of the chairman of the board in committee membership appointment decisions, in order to test formally whether the members of committees are under the pressure of chairmen.

In addition, our findings show that a significantly higher percentage of members of committees are independent directors, compared to non-committee member directors. This also supports the argument that the members of these committees could monitor effectively, based on the assumption that independence could lead to more effective monitoring. In future studies, researchers can investigate the effects of the appointment of independent directors to these committees, especially to governance and risk committees, on firm performance and values, as well as the reaction given by the market to these appointments. What is an interesting observation is the very low percentage of directors that are not audit committee members and are independent. Based on this observation, one could potentially argue that public companies in Turkey potentially do not value the importance of increased monitoring effectiveness that could be provided by independent directors on boards, and they appoint them only 
to meet satisfy regulatory requirements.

In addition, our findings show that a higher percentage of the members of these committees have advanced degrees such as $\mathrm{PhDs}$ and are accounting experts, lawyers or professors. Based on these findings, one could argue that firms potentially value the potential knowledge gained during a higher educational degree and the technical skills of professionals and appoint them to the committees of the boards, in order to benefit from their expertise and unique skills and knowledge. Again, in future studies, researchers can investigate how the market reacts to the inclusion of such directors in board committees, via event studies.

Our findings also suggest that, compared to directors that do not serve on those committees, a significantly higher percentage of the directors serving on committees of the boards are busy directors. However, this is an outcome of the definition of busyness and that it requires directors to be independent in order to be considered as busy. Supporting this argument, the findings show that, on average, directors on the committees of boards, serve on significantly fewer boards of other companies. This figure potentially supports the argument that directors serving on many boards could have time constraints and might not have the time to attend the meetings of committees. Thus, firms do not appoint them to the committees of the boards. In future studies, researchers can investigate the effect of director busyness and directorship numbers of directors, on the likelihood of them being assigned to board committees.

Lastly, our findings suggest that the average share ownership by directors that serve on committees of the boards is significantly lower, compared to other directors. This could potentially be an outcome of the share ownership requirements of the PCG for independent directors. However, it should be kept in mind that share ownership, at least up to a certain point, is a potentially value creating corporate governance mechanism that could motivate the directors to work more effectively in the interests of other shareholders and such regulations could lead to such valuable incentives forgo.

\section{References}

Agrawal, A., \& Chadha, S. (2005). Corporate Governance and Accounting Scandals. Journal of Law and Economics, 48(2), 371-406. http://dx.doi.org/10.1086/430808

Albring, S., Robinson, D., \& Robinson, M. (2014). Audit Committee Financial Expertise, Corporate Governance, and the Voluntary Switch from Auditor-provided to Non-auditor-provided Tax Services. Advances in Accounting, 30(1), 81-94. http://dx.doi.org/10.1016/j.adiac.2013.12.007

Anderson, K. L., Deli, D. N., \& Gillan, S. (2003). Boards of Directors, Audit Committees, and the Information Content of Earnings. Weinberg Center for Corporate Governance Working Paper No. 2003-04.

Anderson, R. C., \& Bizjak, J. M. (2003). An Empirical Examination of the Role of the CEO and the Compensation Committee in Structuring Executive Pay. Journal of Banking \& Finance, 27(7), 1323-1348. http://dx.doi.org/10.1016/S0378-4266(02)00259-5

Arioglu, E. (2013). Essays on Reverse Leveraged Buyouts (Unpublished PhD Thesis). Drexel University, Philadelphia, USA.

Badolato, P., Donelse, D. C., \& Ege, M. (2014). Audit Committee Financial Expertise and Earnings Management: The Role of Status. Journal of Accounting and Economics (forthcoming). http://dx.doi.org/10.1016/j.jacceco.2014.08.006

Beasley, M. S. (1996). An Empirical Analysis of the Relation between the Board of Director Composition and Financial Statement Fraud. The Accounting Review, 71(4), 443-465.

Borokhovich, K. A., Parrino, R., \& Trapani, T. (1996). Outside Directors and CEO Selection. Journal of Financial and Quantitative Analysis, 31(3), 337-355. http://dx.doi.org/10.2307/2331395

Catikkas, O., \& Alpaslan, O. (2013). Efficiency of the Brokerage House Auditing Committees. Mali Çözüm Dergisi, 115, 31-58.

Choi, Y. K., Han, S. H., \& Lee, S. (2014). Audit Committees, Corporate Governance, and Shareholder Wealth: Evidence from Korea. Journal of Accounting and Public Policy (forthcoming). http://dx.doi.org/10.1016/j.jaccpubpol.2014.06.001

Conyon, M. J., \& He, L. (2004). Compensation Committees and CEO Compensation Incentives in U.S. Entrepreneurial Firms. Journal of Management Accounting Research, 16, 35-56. http://dx.doi.org/10.2308/jmar.2004.16.1.35

Dechow, P. M., Sloan, R. G., \& Hutton, A. P. (1996). Causes and Consequences of Earnings Manipulation: An 
Analysis of Firms Subject to Enforcement Actions by the SEC. Contemporary Accounting Research, 13(1), 1-36. http://dx.doi.org/10.1111/j.1911-3846.1996.tb00489.x

Defond, M. L., Hann, R. N., \& Hu, X. (2005). Does the Market Value Financial Expertise on Audit Committees of Boards of Directors. Journal of Accounting Research, 43(2), 153-193. http://dx.doi.org/10.1111/j.1475-679x.2005.00166.x

Dionne, G., \& Triki, T. (2005). Risk management and Corporate Governance: The Importance of Independen and Financial Knowledge for the Board and the Audit Committee. HEC Montreal Working Paper No. 0503.

Dionne, G., Chun, O. M., \& Triki, T. (2013). Risk Management and Corporate Governance: The Importance of Independence and Financial Knowledge. Working Paper. Retrieved from http://ssrn.com/abstract $=2020987$

Fich, E. M., \& Shivdasani, A. (2006). Are Busy Boards Effective Monitors? Journal of Finance, 61(2), 689-724. http://dx.doi.org/10.1111/j.1540-6261.2006.00852.x

Gillan, S. L., Hartzell, J. C., \& Starks, L. T. (2003). Explaining Corporate Governance: Boards, Bylaws, and Charter Provisions. Weinberg Center for Corporate Governance Working Paper No. 2003-03.

Gordon, J. N. (2005). Executive Compensation: If There's a Problem, What's the Remedy? The Case for "Compensation Discussion and Analysis". Journal of Corporation Law, 30(4), 675-702.

Hermalin, B. E., \& Weisbach, M. S. (1991). The Effects of Board Composition and Direct Incentives on Firm Performance. Financial Management, 20(4), 101-112. http://dx.doi.org/10.2307/3665716

Hopt, J. K., \& Leyens, P. C. (2004). Board Models in Europe-Recent Developments of Internal Corporate Governance Structures in Germany, the United Kingdom, France, and Italy. European Company and Financial Law Review, 1(2), 135-168. http://dx.doi.org/10.1515/ecfr.2004.1.2.135

Jensen, M. C. (1993). The Modern Industrial Revolution, Exit, and the Failure of Internal Control Systems. Journal of Finance, 48(3), 831-880. http://dx.doi.org/10.1111/j.1540-6261.1993.tb04022.x

Jensen, M. C., \& Murpy, K. J. (2004). Remuneration: Where We've Been, How We Got to Here, What Are the Problems, And How To Fix Them. ECGI Working Paper Series in Finance Working Paper Series, No. 44.

Jiraporn, P., Singh, M., \& Lee, C. I. (2009). Ineffective Corporate Governance: Director Busyness and Board Committee Memberships. Journal of Banking \& Finance, 33(5), 819-828. http://dx.doi.org/10.1016/j.jbankfin.2008.09.020

Kandemir, T., \& Akbulut, H. (2013). Bağımsız Denetimin Etkinliğinde Denetimden Sorumlu Komitenin Rolü: Türkiye'deki Bağımsız Denetim Firmalarına Yönelik Bir Araştırma. International Journal of Management Economics and Business, 9(20), 37-55.

Karasu, R. (2013). 6102 Sayılı Türk Ticaret Kanunu ile Anonim Şirketlerde Kurumsal Yönetim ile İlgili Getirilen Yenilikler. Journal of the Faculty of Law of Inönü University, 4(2), 33-60.

Karmel, R. S. (2014). Is the Independent Director Model Broken? Seattle University Law Review, 37, $775-811$.

Klein, A. (2002). Audit Committee, Board of Director Characteristics, and Earnings Management. Journal of Accounting and Economics, 33, 375-400. http://dx.doi.org/10.1016/S0165-4101(02)00059-9

Knyazeva, A., Knyazeva, D., \& Masulis, R. W. (2013). The Supply of Corporate Directors and Board Independence. Review of Financial Studies, 26(6), 1561-1605. http://dx.doi.org/10.1093/rfs/hht020

Le Mire, S., \& Gilligan, G. (2013). Independence and Independent Company Directors. Journal of Corporate Law Studies, 13(2), 443-475. http://dx.doi.org/10.5235/14735970.13.2.443

Masulis, R. W., Wang, C., \& Xie, F. (2012). Globalizing the Boardroom - The Effects of Foreign Directors on Corporate Governance and Firm Performance. Journal of Accounting and Economics, 53, 527-554. http://dx.doi.org/10.1016/j.jacceco.2011.12.003

McConnell, J. J., \& Servaes, H. (1990). Additional Evidence on Equity Ownership and Corporate Value. Journal of Financial Economics, 27(2), 595-612. http://dx.doi.org/10.1016/0304-405X(90)90069-C

Morck, R., Shleifer, A., \& Vishny, R. W. (1988). Management Ownership and Market Valuation. Journal of Financial Economics, 20(1-2), 293-315. http://dx.doi.org/10.1016/0304-405X(88)90048-7

Nkoko, B. S., \& Tesfaye, T. L. (2014). Determinants of Voluntary Formation of Risk Management Committees: 
Evidence from an Emerging Economy. Managerial Auditing Journal, 29(7), 649-671. http://dx.doi.org/10.1108/MAJ-02-2014-0998

Nuhoglu, I., \& Armagan, O. (2013). The Status of Audit Committees: A Comparative Study of U.S.A, E.U., and Turkey. MODAV Journal, 15(1), 67-86.

Ozsoy, M. T. (2012). Corporate Risk Management under New Commercial Code. Mali Çözüm Dergisi, 110, $165-185$.

Perry, T., \& Shivdasani, A. (2005). Do Boards Affect Performance? Evidence from Corporate Restructuring. Journal of Business, 78(4), 1403-1432. http://dx.doi.org/10.1086/430864

Shivdasani, A., \& Yermack, D. (1999). CEO Involvement in the Selection of New Board Members: An Empirical Analysis. Journal of Finance, 54(5), 1829-1853. http://dx.doi.org/10.1111/0022-1082.00168

Soliman, M. M., \& Ragab, A. A. (2014). Audit Committee Effectiveness, Audit Quality and Earnings Management: An Empirical Study of the Listed Companies in Egypt. Research Journal of Finance and Accounting, 5(2), 155-166.

Stulz, R. M. (1988). Managerial Control of Voting Rights: Financing Policies and the Market for Corporate Control. Journal of Financial Economics, 20(1-2), $25-54$. http://dx.doi.org/10.1016/0304-405X(88)90039-6

Subramaniam, N., McManus, L., \& Zhang, J. (2009). Corporate Governance, Firm Characteristics and Risk Management Committee Formation in Australian Companies. Managerial Auditing Journal, 24(4), 316339. http://dx.doi.org/10.1108/02686900910948170

Tao, N. B., \& Hutchhinson, M. (2013). Corporate Governance and Risk Management: The Role of Risk Management and Compensation Committees. Journal of Contemporary Accounting \& Economics, 9(1), 83-99. http://dx.doi.org/10.1016/j.jcae.2013.03.003

Uzun, H., Szewczyk, S. H., \& Varma, R. (2004). Board Composition and Corporate Fraud. Financial Analysts Journal, 60(3), 33-43. http://dx.doi.org/10.2469/faj.v60.n3.2619

Walker, D. (2009). A Review of Corporate Governance in UK Banks and Other Financial Industry Entities: Final Recommendations.

Retrieved

from http://webarchive.nationalarchives.gov.uk/+/http:/www.hm-treasury.gov.uk/d/walker_review_261109.pdf

Yatim, P. (2010). Board Structures and the Establishment of a Risk Management Committee by Malaysian Listed Firms. Journal of Management \& Governance, 14, 17-36. http://dx.doi.org/10.1007/s10997-009-9089-6

Yermack, D. (1997). Good Timing: CEO Stock Option Awards and Company News Announcements. Journal of Finance, 52(2), 449-476. http://dx.doi.org/10.1111/j.1540-6261.1997.tb04809.x

\section{Copyrights}

Copyright for this article is retained by the author(s), with first publication rights granted to the journal.

This is an open-access article distributed under the terms and conditions of the Creative Commons Attribution license (http://creativecommons.org/licenses/by/3.0/). 